Article

\title{
Scientific Forest Management Practice in Nepal: Critical Reflections from Stakeholders' Perspectives
}

\author{
Bishnu Hari Poudyal, Tek Maraseni * and Geoff Cockfield \\ Centre for Sustainable Agricultural Systems, University of Southern Queensland, 4350 Queensland, Australia; \\ Bishnuhari.Poudyal@usq.edu.au (B.H.P.); Geoff.Cockfield@usq.edu.au (G.C.) \\ * Correspondence: Tek.Maraseni@usq.edu.au
}

Received: 5 November 2019; Accepted: 19 December 2019; Published: 23 December 2019

\begin{abstract}
Design and application of context-specific forest management practices with the participation of key stakeholders plays a significant role in sustainable forest management outcomes. However, key forestry stakeholders often hold different, and sometimes conflicting, expectations in relation to forest management policies and management objectives. Applying the triple-perspective typology of stakeholder theory, this paper assessed the evolution of "Scientific Forest Management" (SciFM), a signature programme of the Nepalese Government, as well as its policy processes and explored compatibility, complexity, cost and relative advantages of the adoption of SciFM. The government believes that without this programme, Nepal is losing 91 Million US Dollar (USD) per year. This study revealed that participation of key stakeholders remained contested from the beginning of its implementation, primarily due to differences they held in understanding and interpretation of SciFM. Although stakeholders' views converged on the potential role of SciFM to increase forest product supply and the domination of timber-centric management, their perspectives differed in nomenclature and implementation modality of SciFM. Primarily, the community forest users and their networks did not own the concept from the beginning, as they were suspicious of recentralization and bureaucratic dominance in forest governance through SciFM. Since historically ingrained skepticism in both government officials and community forest users' networks towards each other has negatively influenced the trust-building environment, the management of stakeholders' relations through frequent and meaningful deliberations, and the simplification of bureaucratic procedures in implementation and capacity development of key actors could be instrumental in achieving SciFM objectives.
\end{abstract}

Keywords: forest policy; sustainable forest management; silviculture; production forest; forest governance; policy adoption

\section{Introduction}

Life on earth is shaped by the interactions between the environment and society. The theory of coevolution in development explains why and how society and environment intermingles in the development process [1,2]. Since all the resources used by humans are nested in complex socio-ecological systems, scientific knowledge to sustain such systems is essential [3]. Understanding of ecological-technical interactions in forestry and influences of the social actors to define such interactions is critical to enhance forest management and governance outcomes [4]. However, the independent development of social science and ecological science and insufficient efforts to harmonize them has increased the complexity [3]. Taking the case of recent "scientific forest management programme" promoted by the government of Nepal, this paper aims to explore the challenges of harmonizing forest science and the expectations of society through an assessment of stakeholders' perspectives. 
Traditionally, the concept of forest management was developed to mean the scientific management of forests. However, forest management approaches have evolved from the fundamental promise of yield maximisation and sustainable wood production to meeting multiple forest functions [5]. Until the nineteenth century, the application of forest management remained confined to timber production and economic benefits within the domain of technical silviculture [6]. Forest management authorities and scientists promoted a wood-focused approach as "scientific forest management" and a principle doctrine of forestry [7]. It is now realised that the application of forest science is just one aspect of forest management among others, such as economic, social, legal and administrative [8]. As a pioneer science that encompasses the principle of sustainability, forestry science now aims for sustainable forest management (SFM), a dynamic concept that enhances social, economic and environmental benefits of the present generation without compromising the ability of future generations to meet their own needs [9]. Since SFM primarily aims to serve the needs of society, stakeholders' involvement in the design and application of forest management policies is the key to enhancing social, economic and ecological outcomes for people, the economy and the environment. Nevertheless, key forestry stakeholders may have different, and sometimes conflicting, societal expectations in relation to forest management policies and management objectives [10-12]; these differing expectations have often challenged the success of forest management efforts $[13,14]$. Hence, assessment of stakeholders' perspectives is important.

The Government of Nepal began promoting "Scientific Forest Management" (SciFM) (The government has defined it as "an application of appropriate silviculture system and forest management principles through design of systematic compartments of fixed rotation age". This follows primarily the Shelterwood silviculture system with very high intensity logging, leaving only 15-30 mature mother trees per ha.) in 2012 as the programmatic response to address suboptimal forest production, inactive forest management and forest health degradation $[15,16]$. The vision of the government outlined in "Forestry for Prosperity" laid the policy foundation for SciFM as one of the four key pillars of prosperity (Figure 1). Since its pilot implementation in Tilaurakot collaborative forests (a form of community-based forest management (CBFM)) of Kapilvastu district in Nepal's Tarai (Lowland plains of Nepal with high-value natural tropical forests), SciFM now has been expanded to 30 collaborative forests, 285 community forests and seven government block forests [17]. The current focus of government policies, plans and resources is to initiate and implement SciFM irrespective of the forest management regime [18]. Some examples of such focus are approval of SciFM guidelines in 2014, the focus of Forest Policy 2015 on increasing forest productivity and the provision of block forest management through the amendment of the Forest Act 1993 [19].

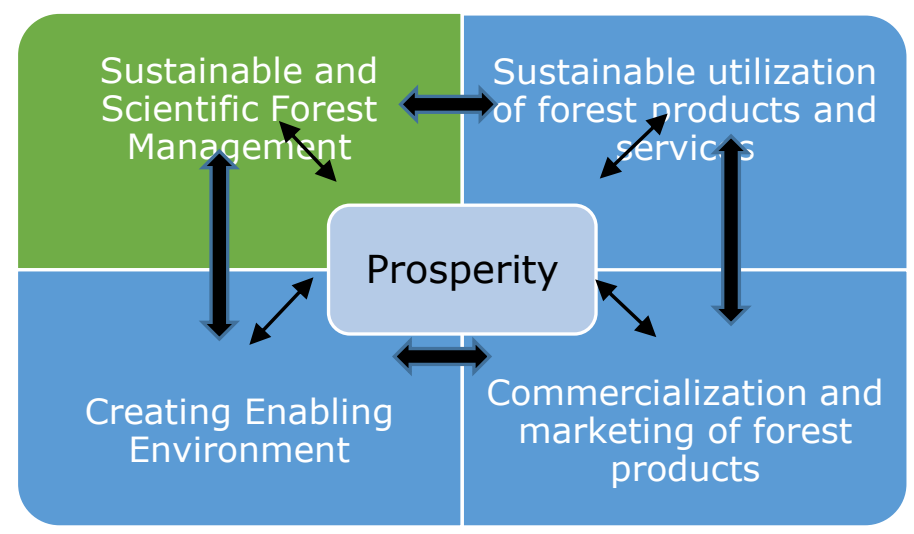

Figure 1. Four pillars of "Forestry for prosperity" (Adapted from Paudel, 2017 [13]).

For many reasons, appropriate forest management intervention is a requirement of Nepal's production forests. With 5.96 million ha of forest area (40.36\% of the country) and 982.3 million cubic meters of total standing stem volume, Nepal has the potential to produce a minimum of 1.66 million $\mathrm{m}^{3}$ 
forest products per annum, creating at least 400,000 sustainable full-time jobs [20,21]. However, existing timber production is less than 0.5 million $\mathrm{m}^{3}$ per year, providing only 45,000 person-days' formal employment [22]. As a result, the country is increasingly importing timber and timber products, to the equivalent to 38 Million USD, almost 65 times higher than the export amount of 0.62 Million USD [23]. Research asserts that Nepal is losing 91 Million USD/year because of its lack of appropriate forest management practices $[18,24]$. Moreover, deterioration in forest quality has been a key issue in the production forests of Terai Nepal. Decrease in growing stock from $178 \mathrm{~m}^{3}$ in 1999 to $164.76 \mathrm{~m}^{3}$ per ha in 2010 [21] has provided evidence of such a decline. Mature trees are obstructing the sunlight in these Sal (Shorea robusta)-dominated forests and are affecting regeneration. The government initiated SciFM to address the concern that conservative and inactive forest management with very low intensity forest harvesting resulted in this situation $[25,26]$.

Despite persuasive reasons being offered to initiate the SciFM approach and extension of its implementation at a larger geographical scale, SciFM has not been able to gain positive momentum in securing the meaningful participation of stakeholders and promoting effective governance in its implementation. In particular, implementation of SciFM in community forests has been widely criticized for the dominance of technical forestry officials and for limiting the role of forest user groups (FUGs) in forest management planning and implementation procedures [27-30]. Likewise, benefit-sharing among stakeholders and transparency of the processes are equally concerning [15,31]. Since one-third of the country's forest area is being managed under community-based forest management regimes [18], any forest management interventions that include these regimes need to satisfy the stakeholders involved. However, the limited number of studies carried out after the promulgation of SciFM are concentrated on either highlighting the positive aspects of site-specific timber production and economic returns [32,33] or on criticising the approach itself in reference to the governance mechanism [28,29]. There is a paucity of knowledge on the perspectives of wider stakeholders and the reasons behind their inactive participation in SciFM implementation procedures.

In the context of encouraging global results from community-based forest management (CBFM) [34,35], the involvement of stakeholders is critically important for assessing resource problems and reaching agreement on the objectives, options and strategies for an effective forest management governance framework [36]. Differences in stakeholders' understandings and conceptualisations of appropriate forest management policies challenge the forest management efforts $[13,14]$. Nepal, renowned as one of the most successful examples of CBFM, despite the country's diverse societal, cultural and environmental contexts [37], has multiple stakeholders at numerous levels who need to be satisfied by any forest management interventions. For instance, the Federation of Community Forest Users, Nepal (FECOFUN) represents 22,266 community forest user groups (CFUGs) as their network at district, provincial and national level and stands as the largest network of grassroots stakeholders in Nepal [36]. Likewise, the Association of Collaborative Forest Users Nepal (ACOFUN), Federation of Forest Based Industry and Trade, Nepal (FENFIT), Himalayan Grassroots Women's Natural Resource Management Association of Nepal (HIMAWANTI) and Community-Based Forestry Supporter's Network, Nepal (COFSUN) are key networks which play a direct role in the implementation of SciFM. Because the voice of these key stakeholders has remained influential in forest management and policy formulations, assessment of their perspectives is important to ensure effective implementation and sustainability of SciFM. Assessment of the stakeholders' perspective is one of the key methods of addressing the divergent views and actions of the stakeholders in forest and resource management $[13,38]$. However, the understandings and perceptions of the key stakeholders in forest management policies and practices are rarely assessed in Nepal.

In this paper, we aim to fill this knowledge gap through a detailed assessment of the stakeholders' perspectives on the adoption of the relatively recent SciFM Programme in Nepal. In doing so, we explore three key questions: (a) what is the stakeholder engagement process in the policy and practice of SciFM? (b) what is the understanding of key forestry stakeholders on SciFM and how they view its relevance and effectiveness? and (c) what might be more effective strategies to manage the natural 
production forests of Nepal? This assessment is crucial to highlight the role of stakeholders in managing the production forests of developing countries in general and it is relevant and beneficial to Nepal to identify the specific reasons behind the inactive participation of the broader stakeholders in the implementation of SciFM.

\section{Methodology}

This study has adopted the concept of forest policy analysis in general and the theoretical framework on stakeholder engagement in deliberations of forest policies and associated issues in particular $[39,40]$. Since diverse stakeholders with their different interests and orientation are engaged to attain forest protection and production objectives as specified by particular forest policy/regulation/guidelines [39], a systematic approach is needed to understand their multiple stakes on such policies and actions. Earlier studies [4,39-44] have suggested and/or applied different theoretical frameworks and methodological approaches while assessing the stakeholders in the forestry and natural resource management sectors. Despite the differences in specific objectives and levels of analysis of those frameworks, interests, power of influences and the position of the stakeholders in designing and implementing forest policies have remained the key common factors as bases for stakeholder analysis. For example, the actor-centred power framework [4] specifically deals with the power sources of actors to define and implement rules and discourses in forest governance. The ultimate aim is to identify the powerful actors to assess their roles and perspectives. Likewise, the participatory backcasting approach [42] attempts to envision the future of forestry from the stakeholder's perspectives, but the bases of stakeholder identification are again the same (i.e., interests, roles and the influences of such stakeholders). Hence, we applied the triple-perspective typology (TPT) of stakeholder theory $[44,45]$ to assess the evolution of SciFM and its implementation, considering interests, management orientation, level of engagement and relationships among the stakeholders as key factors. TPT assists in the assessment of the adoption and effectiveness of any management intervention and offers an analytical tool to evaluate the relationship between stakeholders in aspects of sustainable forest management [44]. TPT assessment comprises three thematic perspectives: conceptual, corporate and general stakeholders/users/consumers. The conceptual perspective explores the relationship and interaction of particular concepts/projects among the stakeholders and how they have influenced each other [45]. The second perspective explores the corporate view or policy promulgator's view; and the final perspective deals with the interest of the consumers/users [44,45]. We categorised the overall SciFM policies and plans as conceptual. Within this aspect, we assessed how the intervention of SciFM affected the economic, social and environmental aspects of forest management [44]. Since SciFM in Nepal is mainly conceptualised as a means of attaining SFM principles, we also categorised the technical, administrative and legal aspects of forest management as falling within the conceptual perspective. Likewise, through the corporate perspective, we examined how the government organisations and private sectors can achieve economic sustainability through equal considerations of societal and environmental issues [46]. Within this category, we assessed whether or not the private sectors and forestry businesses have sufficient supplies of forest products with minimal negative impacts on society and the environment. Finally, a stakeholder-centric perspective provided the focus to canvas the opinions and interests of forest users and their networks/federations that are affected by or can influence SciFM practice on the ground.

The following sections elaborate the processes followed to carry out the study. The first section provides the overview of stakeholder identification and categorization process, whereas the second section explains the detailed methods of data collection.

\subsection{Identification of Stakeholders and Category of Respondents}

We adopted "stakeholder mapping" as the key method to identify and categorise stakeholders [39$41,43,47]$. We developed a stakeholder matrix to assess their roles, interests and power/influences in consultation with policy officials and network representatives $[39,47]$. Further, the history of their 
engagement and position in SciFM was also taken into account [40]. We categorised stakeholders as government agencies, the private sector (including the group/association of contractors), the federation/networks of forest user groups (FUGs) and the FUGs themselves, as defined by Krott [39], to frame the stakeholders under the TPT framework [44]. Then, we categorised the stakeholders into three levels: central level, district level and local/community level. We designed the criteria that included at least one respondent from each level and each identified institution to satisfy the study objective to assess diverse perspectives. The respondents from that specific category were identified based on the stakeholder's recommendation and the level of engagement of that particular individual in design, implementation and negotiation processes of the SciFM policy and guidelines. Their level of engagement was identified based on the existing position and roles, meeting records and interviews with national and local media. In many instances, we found the respondents had double importance considering their current role of implementation and the past engagement in policy development. For example, we selected one key respondent as the chief of planning from the Ministry of Forests and Soil Conservation considering his current role of coordinating forest policy and development under the Ministry and past engagement in policy design as a designated focal person from the Ministry. Table 1 provides details of the stakeholders and their roles/interests in SFM.

Table 1. Identified key stakeholders, their roles/interests and number of respondents.

\begin{tabular}{|c|c|c|c|c|}
\hline $\begin{array}{l}\text { Stakeholder } \\
\text { Group (Total } \\
\text { Respondents) }\end{array}$ & Key Stakeholders & Central/District/Local & $\begin{array}{l}\text { Roles/Interests and Influence in } \\
\text { Sustainable Forest Management } \\
\text { (SFM) }\end{array}$ & Respondents \\
\hline \multirow{5}{*}{ Government (13) } & $\begin{array}{l}\text { Ministry of Forest and } \\
\text { Environment (MoFE) }\end{array}$ & Central & $\begin{array}{l}\text { Promulgating forest policy and plans, } \\
\text { overall coordination and regulation of } \\
\text { forest management activities. }\end{array}$ & 1 \\
\hline & Department of Forests (DoF) & Central & $\begin{array}{l}\text { Drafting forest policy proposals, } \\
\text { negotiation with stakeholders, } \\
\text { coordinating all the district forest } \\
\text { offices, implementation of policies, } \\
\text { plans and oversight of nationwide } \\
\text { forest management activities. }\end{array}$ & 4 \\
\hline & District Forest Office (DFO) & District & $\begin{array}{l}\text { Implementing all forest management } \\
\text { activities in the district. Balancing } \\
\text { protection and production, facilitating } \\
\text { user groups, entrepreneurs and } \\
\text { contractors to balance demand and } \\
\text { supply. }\end{array}$ & 6 \\
\hline & $\begin{array}{l}\text { Timber Corporation of } \\
\text { Nepal (TCN) }\end{array}$ & Central & $\begin{array}{l}\text { Harvesting, collection and sales of } \\
\text { timber and fuelwood. }\end{array}$ & 1 \\
\hline & $\begin{array}{l}\text { TCN owned Sawmill at } \\
\text { Danda, Nawalparasi }\end{array}$ & District & $\begin{array}{l}\text { Processing of logs and production of } \\
\text { value-added products such as ready } \\
\text { to sell poles, frames. }\end{array}$ & 1 \\
\hline \multirow{5}{*}{$\begin{array}{l}\text { Federation/networks } \\
\text { of forest users (12) }\end{array}$} & $\begin{array}{l}\text { Federation of Community } \\
\text { Forest Users Nepal } \\
\text { (FECOFUN) }\end{array}$ & Central & $\begin{array}{l}\text { Ensuring community rights in forest } \\
\text { policies, action plans and regulations } \\
\text { through active engagement in policy } \\
\text { processes and advocacy. Facilitating } \\
\text { community forest users to utilize their } \\
\text { rights and building capacity of users }\end{array}$ & 4 \\
\hline & District/area level FECOFUN & District & $\begin{array}{l}\text { Coordinating at district level with } \\
\text { forest office, management plan } \\
\text { implementation }\end{array}$ & 4 \\
\hline & $\begin{array}{l}\text { Community-based Forestry } \\
\text { Supporter's Network } \\
\text { (COFSUN) Nepal }\end{array}$ & Central & $\begin{array}{l}\text { Building capacity of forest user } \\
\text { groups and facilitating policy process. }\end{array}$ & 1 \\
\hline & $\begin{array}{l}\text { Association of Collaborative } \\
\text { Forest Users Nepal } \\
\text { (ACOFUN) }\end{array}$ & Central & $\begin{array}{l}\text { Advocating users' rights in policies } \\
\text { and plans. Facilitating } \\
\text { implementation of Collaborative } \\
\text { Forest Management (CFM) activities. }\end{array}$ & 2 \\
\hline & $\begin{array}{c}\text { Himalayan Grassroots } \\
\text { Women's Natural Resource } \\
\text { Management Association of } \\
\text { Nepal (HIMAWANTI) }\end{array}$ & Central & $\begin{array}{l}\text { Empowering women in forest } \\
\text { management, policy advocacy, } \\
\text { capacity development of Community } \\
\text { Forest User Groups (CFUGs). }\end{array}$ & 1 \\
\hline
\end{tabular}


Table 1. Cont

\begin{tabular}{|c|c|c|c|c|}
\hline $\begin{array}{l}\text { Stakeholder } \\
\text { Group (Total } \\
\text { Respondents) }\end{array}$ & Key Stakeholders & Central/District/Local & $\begin{array}{l}\text { Roles/Interests and Influence in } \\
\text { Sustainable Forest Management } \\
\text { (SFM) }\end{array}$ & Respondents \\
\hline \multirow{3}{*}{ Private Sector (8) } & $\begin{array}{l}\text { Federation of Forest Based } \\
\text { Industry and Trade, Nepal } \\
\text { (FENFIT) Nepal }\end{array}$ & Central & $\begin{array}{l}\text { Advocating for enabling environment } \\
\text { to the forest products industries, } \\
\text { sustainable supply of timber products }\end{array}$ & 3 \\
\hline & Saw mills & Central plus Local & $\begin{array}{l}\text { Collecting forest products at local } \\
\text { level and sustainable supply of timber } \\
\text { and local furniture. }\end{array}$ & $3(1+2)$ \\
\hline & Local timber contractors & Local & $\begin{array}{l}\text { Collecting forest products and supply } \\
\text { in other places. }\end{array}$ & 2 \\
\hline \multirow[b]{2}{*}{$\begin{array}{l}\text { Forest user groups } \\
\text { (7) }\end{array}$} & $\begin{array}{l}\text { Community forestry user } \\
\text { groups }\end{array}$ & Community & $\begin{array}{l}\text { Conservation and management of } \\
\text { forest areas handed over to them. }\end{array}$ & 5 \\
\hline & $\begin{array}{l}\text { Collaborative forest } \\
\text { management } \\
\text { committee/users }\end{array}$ & Community & $\begin{array}{l}\text { Interested in sustainable supply of the } \\
\text { forest products for their subsistence } \\
\text { needs. } \\
\text { Influence on local forest management } \\
\text { decisions/regulations through their } \\
\text { networks. }\end{array}$ & 2 \\
\hline Total & & & & 40 \\
\hline
\end{tabular}

\subsection{Data Collection and Analysis Methods}

As the study required detailed information from individuals directly involved in policy formulation and the implementation of SciFM, purposive sampling techniques as suggested by Yin [48] and Babbie [49] were used to identify the respondents for key informant interviews (KII) and the participants in meetings/workshops. This technique is more accurate and reliable for gathering information related to policy and its implementation [50]. Semistructured in-depth interviews were conducted to answer questions related to socio-political and economic aspects and to provide an opportunity to subjectively understand and interpret the conversations [51] around SciFM.

Moreover, we assessed the performance of SciFM based on compatibility, complexity, relative advantage and costs of adoption. These are the key attributes applied to investigate the factors affecting adoption of any interventions [52,53]. Compatibility of any actions/innovations is the degree to which an intervention is consistent with the existing norms/values of the environment and society [52]. Likewise, the complexity and relative advantage of any interventions are the degree of difficulty in adoption and the degree of being better compared with the earlier ideas or existing interventions $[52,53]$. For this study, compatibility was evaluated based on the needs of forest condition/type, topography, environmental sensitivity, demands of market and society and consistency with forest management principles/objectives of specific management regimes. Complexity was evaluated against the level of technical capacity required, the procedures followed to approve management plans, clarity in legal procedures and authority delegation and other administrative difficulties. We examined relative advantage based on the experience of stakeholders on economic profitability and associated social and environmental benefits compared with the previous management practices. Finally, we assessed the stakeholders' responses on start-up costs of the intervention and the capacity of the stakeholders to bear those costs. We recorded the responses on these attributes in three categories: high, medium and low. This rating was based on the respondents' subjective judgement on each sub-criterion of the four attributes and comparison with the traditional forest management approach. Assessment of these attributes focused on stakeholders' behaviour, understanding and opinions of SciFM.

Although the questions were designed to explore the institutional perspectives of the respondents, divergent views within an institution were recorded separately and presented in percentages. In our results and discussion, we consider a view as "institutional" if more than 50 per cent of the respondents shared the same view. To verify and triangulate the information received from interviews, we (1) conducted half-day stakeholders' workshops at the local and national level, in which 38 representatives from different stakeholder organisations participated; and (2) undertook 
expert consultations with five independent researchers and forestry professionals who have been critically engaged in assessing SciFM activities since its initiation. Moreover, the author attended a three-day "National Workshop on Collaborative Forest Management" in March 2018 in Janakpur, Nepal and witnessed the discussions among key actors on SciFM implementation. This offered a prime opportunity to visualise the context of SciFM.

\section{Results}

\subsection{Engagement of Stakeholders in SciFM Policies and Processes}

Key stakeholders exhibited mixed reactions to the policy formulation process and implementation modality of SciFM. All the respondents from the government considered that the vision "Forestry for Prosperity" that laid the foundation for promotion of SciFM was formulated through more comprehensive consultations with all the key forestry stakeholders and that the actions planned to achieve the vision were agreed by all. Their claim was that the key essence of the vision was intensification of forest management for timber production based on forestry science. On the other hand, community forests network leaders at the central level responded that they agreed with the vision as it opened up an avenue for active management of production forests and was discussed with the respective stakeholders. However, the implementation modality of that vision was never discussed. "There was no discussion on action plans and implementation procedures with the stakeholders," one of the central leaders of FECOFUN stressed. A common argument of the leaders from HIMAWANTI, FECOFUN and COFSUN was that the government was pushing for the SciFM without piloting or demonstrating the effectiveness of SciFM. However, a senior forestry officer from the forest department disagreed with this opinion, stating that all the stakeholders were regularly invited to the policy discussions and had the opportunity to participate in the policy and implementation process where their input was deemed necessary. Representatives from the private sector working in forest-based enterprises also agreed that the SciFM implementation modality required more discussions among the key stakeholders; they argued that the programme was timely and must progress to fulfil the timber demands of the country.

Representatives from ACOFUN expressed their satisfaction with stakeholder engagement in the policy processes of SciFM but reported that they had inadequate facilitation support from the government in its implementation. FUGs reported that their role in the conceptualisation and policy formulation process was negligible, despite their forest management rights. They reflected that users were ignorant of the policy and action plans until the respective district forest officials announced the programme and presented its associated benefits/incentives with them. On the other hand, a senior government officer engaged in the SciFM policy process reflected that network leaders were equally responsible for conveying the message to their local users. These scenarios emphasise that participation of key stakeholders in the development of SciFM has remained contested since the beginning of its implementation.

\subsection{Conceptualisation/Understanding of SciFM among Stakeholders}

Our results revealed that different stakeholders have understood SciFM differently (Table 2). However, their dominant views converged on the point that SciFM supports economic development through improved wood supply scenarios and promotes timber-centric management. Almost all of the respondents from the government, private sector and ACOFUN understood SciFM as one of the main management frameworks to achieve SFM through active silviculture operations and saw it as the only option to avoid increasing timber imports. During verification, the group of experts also reflected that understanding. Even the respondents from FECOFUN and their local users agreed that if the governance of timber management get improved, this will help to improve internal wood product supply and minimise imports. At the same time, their views differed on the implications of this timber-centric management on biodiversity and traditional knowledge of the communities. 
Dominant respondents from FECOFUN, COFSUN and HIMAWANTI stressed that this initiative is against the principle of SFM because it ignored the environmental and biodiversity aspects of forests. District- and central-level government officials did not agree with this response and claimed that SciFM offered more opportunities to regenerate and improve forest quality by removing old growth. They considered that the government has treated those areas sensitive to biodiversity conservation and watershed protection separately. Moreover, a local forest officer stressed, "SciFM is equally sensitive to maintain these functions" despite the primary objective of SciFM being forest production.

Table 2. Perspectives of stakeholders on SciFM (Scientific Forest Management) concept and implementation modality.

\begin{tabular}{|c|c|c|}
\hline Stakeholders & Conceptualisation/Understanding of Scifm & No. of Respondents \\
\hline \multirow{4}{*}{ Government } & $\begin{array}{l}\text { Active form of science- based management of production forest for } \\
\text { sustainable supply of timber and fuelwood, thereby minimising timber } \\
\text { imports. }\end{array}$ & $13(100 \%)$ \\
\hline & a. Current modality is perfect, at least in natural forest of terai. & $8(62 \%)$ \\
\hline & b. It is just piloting and need to rethink context specific approach. & $3(23 \%)$ \\
\hline & $\begin{array}{l}\text { c. We could have simplified and facilitated the earlier form of } \\
\text { harvesting by just improving the governance. }\end{array}$ & $2(15 \%)$ \\
\hline \multirow{4}{*}{$\begin{array}{l}\text { Forest Network and } \\
\text { Federations }\end{array}$} & $\begin{array}{l}\text { A management initiative where forest is seen for only the timber and } \\
\text { money rather considering biodiversity, traditional knowledge and } \\
\text { social aspect of forests. this is the form where technicians increase their } \\
\text { role and have imposed scifm through policy and incentive for the short } \\
\text { term, aiming to recentralise cfug rights. }\end{array}$ & $5(42 \%)$ \\
\hline & $\begin{array}{l}\text { A form of active forest management of natural forests of terai that has } \\
\text { addressed the timber and fuelwood needs of distant users as well as } \\
\text { supply at national level. ongoing management modality and procedure } \\
\text { is fine. }\end{array}$ & $3(25 \%)$ \\
\hline & $\begin{array}{l}\text { Although the current modality is more beneficial for forest and } \\
\text { community, this demands more capable local forest user groups. } \\
\text { therefore, this can be piloted in cfugs that are better in terms of } \\
\text { governance and group management. system should be flexible for } \\
\text { different management regime. }\end{array}$ & $2(17 \%)$ \\
\hline & $\begin{array}{l}\text { Scifm is the government- led programme imposed on all the cfugs. } \\
\text { regular harvesting as per the inventory of growing stock best fits cfugs. }\end{array}$ & $2(17 \%)$ \\
\hline \multirow{3}{*}{ Private Sector } & $\begin{array}{l}\text { Scifm is an active forest management modality to increase timber } \\
\text { supply, to reduce timber price in the market and replace current } \\
\text { imports. this will maintain sustainability of forest product supply and } \\
\text { help to improve forest governance. }\end{array}$ & $8(100 \%)$ \\
\hline & $\begin{array}{l}\text { a. The current modality is fine for the moment. however, it would be } \\
\text { good if the government managed to sell the standing trees through } \\
\text { tender rather than going for separate bidding and contracting process. }\end{array}$ & $5(62.5 \%)$ \\
\hline & $\begin{array}{l}\text { b. The current form of harvesting and sales requires stringent rules to } \\
\text { control irregularities and the influence of local contractors/groups. }\end{array}$ & $3(37.5 \%)$ \\
\hline \multirow{3}{*}{ Forest User groups } & $\begin{array}{l}\text { Scifm is an approach that encourages users to be active in forest } \\
\text { management and increases timber and fuelwood supply, increases } \\
\text { income of the forest user groups and employment of the local users. we } \\
\text { can invest more in community development. current form of } \\
\text { management is fine. }\end{array}$ & $3(43 \%)$ \\
\hline & $\begin{array}{l}\text { Scifm primarily focuses on the increased role of technicians and the } \\
\text { local users. this also supports increased income and employment, but is } \\
\text { challenging to the users to maintain post-harvest management, mainly } \\
\text { in protecting forest fire/grazing. that is why cfug with low income, } \\
\text { ineffective group management and the bad governance } \\
\text { record/performance should not go for scifm. there are more risks } \\
\text { associated with this approach. therefore, this modality needs further } \\
\text { testing among capable cfugs and should focus more on capacity } \\
\text { development of local users. }\end{array}$ & $3(43 \%)$ \\
\hline & $\begin{array}{l}\text { Scifm is not good for cfugs. our use rights might be at risk due to } \\
\text { technocratic dominance. }\end{array}$ & $1(14 \%)$ \\
\hline Total & & 40 \\
\hline
\end{tabular}


Furthermore, the central- and district-level FECOFUN leaders saw the SciFM approach as an intention of the government to recentralise the rights of CFUGs, thereby demonstrating that forest management needs higher technical inputs that are beyond the capacity of local users. However, central and local leaders of collaborative FUGs support the SciFM and did not see this as a recentralising strategy but suggested better administrative management. Likewise, understanding of local FUGs was mixed, indicating their confusion and the dearth of discussion on the topic. Their dominant view on SciFM was that it is a form of forest management under which they can harvest the green trees (that was not the usual case before) and fulfil the demands of local people. CFUGs equally understood SciFM as a science-based approach in which technicians are the masters and users play a negligible role in harvesting decisions as they have less capacity to deal with high-intensity harvesting planning and technical management. Nevertheless, around 40 per cent of respondents from the local forest user category felt encouraged to support SciFM, with the notion that users also need to be more proactive in understanding the technical aspects of forests, just as in the agricultural sector, where farmers are able to deal with many aspects of crop production.

In terms of ongoing modality and the management procedure, stakeholders, even within the same institutions, expressed divergent views. More than half of the total government respondents considered that the current modality of SciFM was the best option for managing production forests in Nepal. On the other hand, one fifth of respondents considered that the current form of SciFM needed contextual modification, and a small number of them responded that SciFM as such was not necessary if the forest management and harvesting provision of forest management plans were to be implemented appropriately. Among the respondents from the forest networks and federations category, only a quarter of the total respondents were positive towards this modality, whereas more than half asked for a redesign of the modality in consultation with stakeholders (Table 2). Likewise, the dominant respondents from the private sector were satisfied with the current modality of SciFM and reflected that sales of standing trees could further facilitate the improvement of governance and reduce timber costs in the supply chain. Within the category of FUGs, more than 40 per cent of respondents were satisfied with the current modality, with the other half expressing the need for further testing before implementing it in all forest management regimes.

\subsection{Relevance of SciFM}

Results revealed that stakeholders, except the central leaders of CFUG networks, considered the SciFM programme to be compatible (responding to the needs of the forest condition, the demands of market and society, and being consistent with forest management principles) and of higher relative advantage (compared with the previous management regimes) in Nepal's production forests. However, responses to the level of compatibility and relative advantage were different within the stakeholders' group. About 85 per cent of the total respondents from the government agencies rated this as highly compatible, whereas private sector respondents viewed it as having only medium compatibility, suggesting the possibility of improvement in its modality. Among the four groups, the forest networks and federations had mixed opinions in terms of the programme's compatibility, with nearly half of the respondents considering it to be less compatible. Generally, the central-level network leaders claimed that it was not compatible as they had not been able to address the needs and priorities of the forest users. Local-level leaders and the forest users rated compatibility as a medium to high.

Specifically, stakeholders rated the overall relative advantage of SciFM as higher compared with the earlier low-intensity timber harvesting practices in natural forests. With the exception of the community forest user networks, the stakeholder group responded that the relative advantage was higher compared with the earlier forest management. However, the percentage of respondents differed as per the stakeholder groups. For example, 85 per cent of the government respondents viewed SciFM as more beneficial, whereas 50 per cent and 57 per cent of the respondents from the private sector and FUGs, respectively, perceived SciFM as having greater advantages. However, the majority of respondents from central level networks rated SciFM as relatively less advantageous than the 
earlier approach because of the higher risks of technical dominance, more investments and negligible attention to forest biodiversity. Interestingly, the local FUGs and even the local leaders of the networks considered SciFM to be more advantageous than before, but central-level leaders of the network rated the advantages as low.

\subsection{Effectiveness of SciFM}

Respondents argued that the apparent effectiveness of SciFM did not encourage them to adopt it as the programme because it was seen to be complex and costly (Figure 2). Assessment of the attribute "complexity" reflects that SciFM as such was a complex initiative for the stakeholders, mainly due to insufficient technical human resources to facilitate the programme, low capacity of the local forest users, challenges to ensure good governance in timber production chains and, most importantly, different understanding/lack of consensus among the stakeholders. Except for the private sector, all three stakeholder groups rated "complexity" as high. Even the government respondents, who strongly advocated SciFM, rated its implementation as complex. Dominant respondents (more than 70 per cent) from local FUGs and their leaders at local and national level responded that SciFM was a highly complex programme due to its dominance by forest science and governance procedures. Very few respondents from the government or the private sectors considered that SciFM implementation was low in complexity.
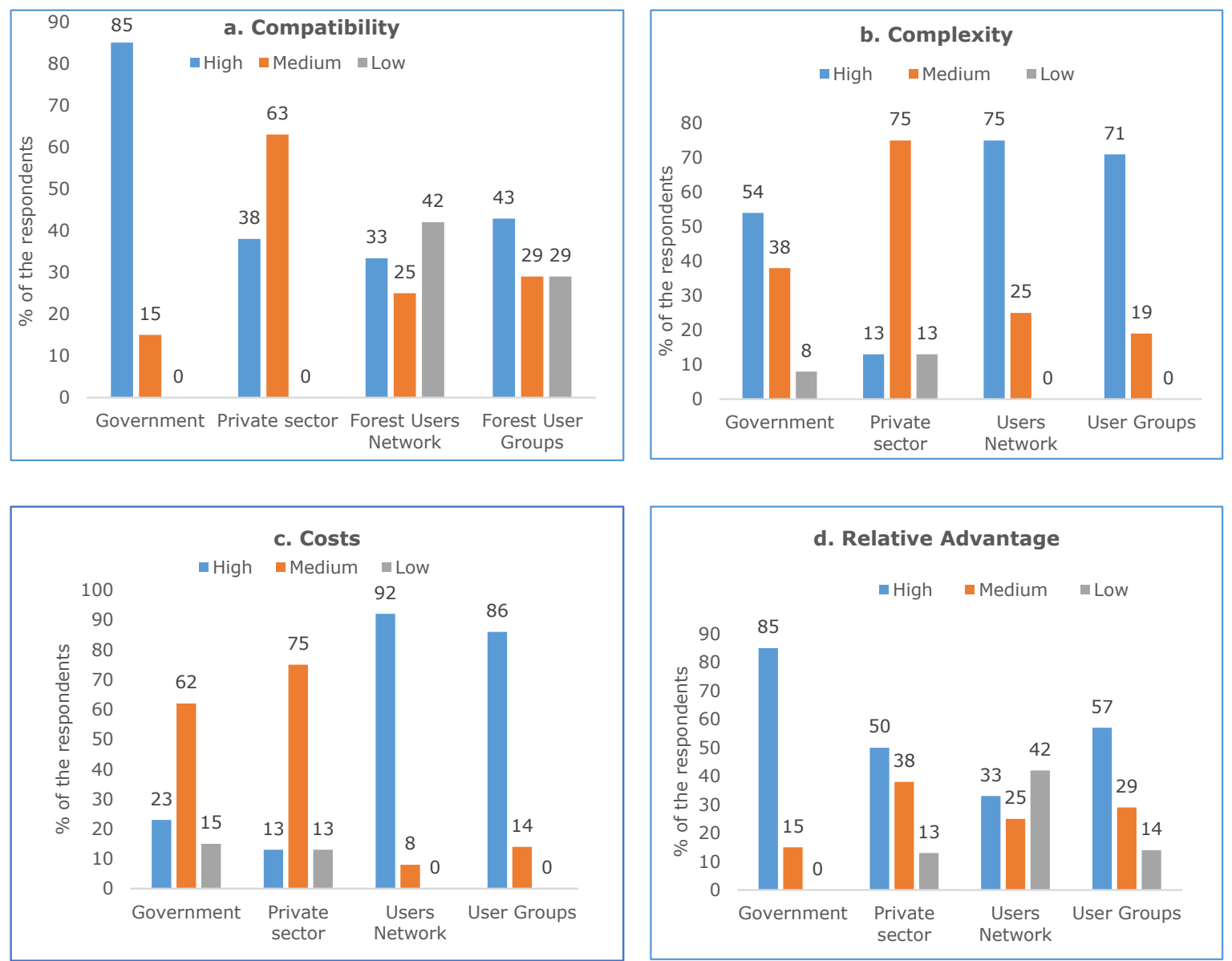

Figure 2. Stakeholder's perspectives on SciFM based on the key attributes $(n=40)$ (a) compatibility of SciFM, (b) complexity of SciFM, (c) costs of SciFM adoption and (d) relative advantage of SciFM.

Regarding the overall cost incurred in the implementation of SciFM, respondents from the government and private sector rated the cost as medium compared to the level of direct income from forest harvesting. However, more than 85 per cent of the respondents from FUGs and civil society 
networks reported high costs in its implementation, primarily the maximum start-up costs during the operational plan approval process. Their view was that it was too costly for local FUGs to get the SciFM plan approved, because they needed to hire a number of forestry technicians for the detailed inventory and tree-tagging process. The private sector view was that if the overall cost was considered over the longer term, it was seen as medium: forest management groups did not need to invest the same amount each year for harvesting compared with the first year of its implementation. Respondents from the government agreed with this logic and seemed confident that the cost would be reduced by the increased skills and experience of the forestry professionals as well as the forest groups.

\subsection{Opportunities and Challenges of SciFM Implementation}

The stakeholders believed that SciFM faced a number of challenges but at the same time, created numerous opportunities to improve the forest condition, and enhance economic benefits as well as to develop the forest management capacity of forestry stakeholders. Nevertheless, the opportunities and challenges foreseen by the stakeholders were different. All the stakeholders agreed that SciFM would increase the forest product supply to replace forest product imports and develop the institutional capacity of government as well as forest users in forest harvesting and management. Likewise, all other stakeholders, except FECOFUN and COFSUN, agreed that SciFM would create more jobs and income for the local people and would contribute more revenue to the national economy. They viewed such benefits as being for the short term, as the community would suffer more due to technical difficulties and financial irregularities within user groups. Table 3 highlights the key opportunities identified by the stakeholders, ranked according to the statements that were agreed to by the majority.

Table 3. Stakeholders views on key opportunities of SciFM implementation.

\begin{tabular}{|c|c|}
\hline Opportunities & In the View of \\
\hline $\begin{array}{l}\text { Increase in forest product supply to replace imports } \\
\text { of forest products }\end{array}$ & $\begin{array}{l}\text { Government, Private sector, Forest user groups, } \\
\text { ACOFUN, FECOFUN, COFSUN, HIMAWANTI }\end{array}$ \\
\hline $\begin{array}{l}\text { Development of institutional capacity of forest } \\
\text { management agencies and forest user groups in } \\
\text { silviculture-based forest management }\end{array}$ & $\begin{array}{l}\text { Government, Private sector, Forest user groups, } \\
\text { ACOFUN, FECOFUN, COFSUN, HIMAWANTI }\end{array}$ \\
\hline $\begin{array}{l}\text { Creation of more jobs and income for the local people } \\
\text { and higher contribution to national economy }\end{array}$ & $\begin{array}{l}\text { Government, Private sector, ACOFUN, Forest user } \\
\text { groups, HIMAWANTI }\end{array}$ \\
\hline Improvement in forest conditions & $\begin{array}{c}\text { Government, Private Sector, ACOFUN, Forest user } \\
\text { groups }\end{array}$ \\
\hline $\begin{array}{l}\text { Increase in motivation/participation of community } \\
\text { members in forest management activity due to } \\
\text { increased investment opportunities in community } \\
\text { development and supporting poor households }\end{array}$ & $\begin{array}{c}\text { Government, Private sector, ACOFUN, Forest user } \\
\text { groups }\end{array}$ \\
\hline $\begin{array}{c}\text { Change in conservation-focused perspectives on } \\
\text { forest management }\end{array}$ & Private sector, ACOFUN \\
\hline $\begin{array}{l}\text { Technological advancement in forest harvesting and } \\
\text { value addition in timber products }\end{array}$ & Private sector \\
\hline Improvement in forest governance & Private sector \\
\hline
\end{tabular}

The most common challenge, as perceived by the stakeholders, was the limited capacity of the implementers, mainly the forest officials and FUGs (Table 4). Likewise, the key challenges highlighted were lengthy bureaucratic procedures for forest harvesting and sales, lack of consensus among the stakeholders, maintaining transparency and governance in the timber production chain, ensuring users' rights, minimising the costs and simplifying the complexity of the process. 
Table 4. Stakeholders' views on key challenges of SciFM implementation.

\begin{tabular}{|c|c|}
\hline Challenges & In the View of \\
\hline $\begin{array}{c}\text { Limited capacity of forestry staff to facilitate SciFM at } \\
\text { local level due to multiple roles and lack of forest } \\
\text { management skills }\end{array}$ & $\begin{array}{l}\text { Government, FECOFUN, ACOFUN, COFSUN, } \\
\text { HIMAWANTI, Private sector, Forest user groups }\end{array}$ \\
\hline $\begin{array}{l}\text { Lengthy bureaucratic procedures for harvesting and } \\
\text { sales (tender call and approval) and lack of quick and } \\
\text { efficient monitoring system (limited authority to } \\
\text { District Forest Office (DFO) and multiple layers of } \\
\text { monitoring) }\end{array}$ & $\begin{array}{c}\text { FECOFUN, ACOFUN, COFSUN, Private sector, } \\
\text { Forest user groups }\end{array}$ \\
\hline $\begin{array}{l}\text { Poor governance in wood production flow and lack } \\
\text { of transparency in implementation procedures }\end{array}$ & $\begin{array}{c}\text { FECOFUN, COFSUN, HIMAWANTI, Private sector, } \\
\text { Forest user groups }\end{array}$ \\
\hline Safety of forest workers & FECOFUN, ACOFUN, Forest user groups \\
\hline $\begin{array}{l}\text { Conservation-oriented mindset of stakeholders and } \\
\text { the public }\end{array}$ & Government, ACOFUN, Private sector \\
\hline Expensive start-up cost & $\begin{array}{l}\text { FECOFUN, COFSUN, HIMAWANTI, Forest user } \\
\text { groups }\end{array}$ \\
\hline $\begin{array}{l}\text { Different understanding and views of } \\
\text { stakeholders/political leaders and relationship } \\
\text { management/coordination with FECOFUN }\end{array}$ & Private sector, Forest user groups \\
\hline $\begin{array}{l}\text { High fiduciary risks in timber harvesting and sales } \\
\text { (maintaining timber governance) }\end{array}$ & FECOFUN, COFSUN, Private sector \\
\hline Lack of specific harvesting and thinning guidelines & Government \\
\hline $\begin{array}{l}\text { Sustainable investment in stand management and } \\
\text { thinning, post-harvesting stand management }\end{array}$ & Government, ACOFUN, Private sector \\
\hline
\end{tabular}

\section{Discussion}

Governments promulgate policies on appropriate forest management practices in accordance with forest resource conditions and their own forest management objectives. Nevertheless, key forestry stakeholders may have different, and sometimes conflicting, societal expectations in relation to forest management policies, including forest resource conditions and management objectives [10-12]. Therefore, it is crucial to reflect critically on the conceptual perspectives of the stakeholders. This is also essential in participatory policy and initiatives such as community-based forest management [44,54-56]. Our results indicated that despite the convergence of stakeholders' agreement on the need for active forest management, lack of sufficient and effective deliberations among stakeholders in SciFM policy processes resulted in diverse understandings and conceptualisation of SciFM in Nepal. Their key concern was that although SciFM has long-term implications on social, environmental and economic aspects of forest-dependent communities, they were rarely consulted before implementation. The following sections suggest reasons why such conceptual understanding may be different among the stakeholders (conceptual perspective), what could be the implications of such diverse conceptualisations for the corporate goal of supplying forest products and improving forest-based economy (corporate perspectives) and finally, why meeting the needs and interests of FUGs and their networks (stakeholders' perspective) is central to making any community-based forest management policy a success.

\subsection{Potential Reasons and Implications of Differences in Conceptual Understandings of SciFM among Stakeholders}

Some of the potential reasons for differences in SciFM perspectives could be (a) lack of sufficient deliberations on the SciFM policy process and its implementation modality; (b) political economy of the stakeholder's institutions and expectations of the FUGs; (c) ingrained skepticism towards each other (government and civil society networks). The study findings revealed that the root cause of 
diverse perspectives on SciFM among the stakeholders is associated with the name and modality of the programme. The network leaders had disagreed on the term "Scientific" from the beginning due to its implication of inherent dominance by forest technicians [57]. Because the essence of community-based forestry is participation and ownership of local people to manage their resources according to the set management objectives [34,58], the argument put forward by the networks seems reasonable to the extent that the current form of SciFM modality needs more technical skills relating to forest science and may demotivate communities from engaging actively. Such examples of the decreased roles and interests of local people in the decision-making process of SciFM have already been revealed [29]. On the other hand, government officials view the term "scientific" as relevant as it supports the communication of all the stakeholders on the need for active silvicultural operations to be based on forest science. Their view supports the claim that the conservation-oriented mindset of the stakeholders and inactive silviculture has constrained optimisation of the economic potential of forests [25,26]. However, the terminology itself might not be such a big issue if stakeholders came together and initiated intense deliberations on SciFM plans and modality. Strong disagreement of FECOFUN, HIMAWANTI and COFSUN (central-level networks) on the implementation modality of SciFM and their feelings of bureaucratic dominance in policy and implementation processes also indicate poor policy deliberations.

Moreover, the realisation of practical difficulties by other stakeholders (including timber entrepreneurs and ACOFUN) and validated by the experts who are positive about SciFM implementation also supports the claims of insufficient consultative discussions during preparation of policies and plans. On the other hand, stakeholders' appreciation of the vision of "forestry for prosperity" but resistance to SciFM modality signifies their minimum efforts to understand and negotiate the procedural aspects of forest management, indicating the political economy behind their perspectives. Since offering a platform for policy deliberations and facilitating meaningful participation and support to articulate the interests, preferences and values of the society $[54,56,58,59]$, the government, as a key leader in the policy process, needs to initiate the steps [60] and realise that merely sharing the vision might not reflect the societal interests. As highlighted by Shindler, et al. [61], if policies and plans do not adequately address the concerns of people, their representative networks remain unstable despite the scientific and economic rigor of such policies and plans.

The economic and political interests of stakeholders and their expectations remain key determinants in CBFM practices. To be specific, better stakeholder relations are necessary conditions for creating an enabling environment to achieve the prosperity vision [16] for which SciFM is designed. However, the history of participatory forest policy and practice in Nepal conveys the ingrained dominance of government bureaucracy despite several waves of deliberative politics [62]. Since stakeholders have witnessed events where the conventional techno-bureaucratic authority has constrained the autonomy of FUGs [28,62-64], stakeholders suspect that the implementation of SciFM will herald the revival of recentralized forest management. Further, the productive, high-value forests of Nepal's Tarai have always been a focus of conflict [65-67] among the stakeholders due to their diverse interests being dominated by political and economic considerations and motivations. Cases from community forests implementing SciFM have revealed that forest management decisions under SciFM are predominantly guided by the forest administration [29]. This might have further discouraged FUGs and their networks from taking part in SciFM and fuelled disagreement over the forest management modality.

While these issues are valid on their own, differences among key stakeholders are often conceptualised based on their conventional thinking, founded on their institutional and political bases [13]. It might be the case that such conventional thinking can exert a direct influence in exacerbating the divergence. This argument is supported by the deep-rooted scepticism held by the community networks (primarily in FECOFUN) towards government as the "controller" and the impression of forest management agencies of the government of networks as "problem makers". Such scepticism towards government is not an exception for a country like Nepal, where the reluctance and resistance of forest bureaucracy to translate democratic decentralization at the local level is often 
perceived by the forest users $[62,68]$. Likewise, negative perceptions of community networks are also becoming common among government agencies due to these networks' consistent resistance to forest plans and policies, sometimes even related to ordinary issues not backed up by evidence [64]. However, conventional thinking of stakeholders may mislead and pose serious constraints to improved communication, trust and effective collaboration [13]. Therefore, identification of the dissenting factors and sharing of perspectives through frequent deliberations is a crucial way to facilitate successful collaboration on SciFM in Nepal.

In line with our study findings, differences in conceptualization and understanding of SciFM and a lack of trust among key stakeholders are the root causes of conflict. Different interpretations of any concept/intervention by different stakeholders may lead to the generation of a number of problems that can cause the failure of any intervention. Examples from Finland on traditional versus scientific forest management [7] and from the Pacific on appropriate forest management practices [13,61] provide evidence of such failures. Therefore, identification of the conceptual space of "Scientific Forest Management" as well as increased communication and collaboration for trust building are crucial to solving the problem.

\subsection{Relevance and Effectiveness of SciFM}

Stakeholders have different perspectives on the relevance and effectiveness of SciFM. In general, the positive responses of the majority of the stakeholders in our study reflect the higher relative advantage and compatibility of this intervention, indicating the higher rate of adoption of SciFM [52]. Nevertheless, conflicting views and contestations between two key stakeholders, that is, the Forestry Department and FECOFUN, will have negative effects on the adoption of SciFM. Nearly 85 per cent of the government respondents (all of whom are forest technicians) viewed SciFM as a highly compatible approach of forest management. Their responses indicate that even the technically sound government staff had thought very little about other possible options than the SciFM modality. On the other hand, FECOFUN claimed that it was irrelevant from the very beginning, even without any detailed field-based evidence. Neither of the stakeholders has considered the flexibility in the modality based on the forest condition, species and type of forest management regime. Because management modality needs to respond to the diversity in forest management objectives, forest types and ownership [14,69], rigid perspectives of stakeholders on the current modality reduce the effectiveness of SciFM. As highlighted by Shindler, Brunson and Stankey [61], a lack of social acceptability of any practices makes them vulnerable to public rejection. Therefore, it is important to pay serious attention to the stakeholders' concerns to enhance the effectiveness of SciFM. Positive responses from the private sector as well as user groups at the local levels on the compatibility of SciFM indicate their interests on harvesting timber and fuelwood so that they can increase supply in the markets and to the community groups, respectively. Since forest harvesting policies and practices in Nepal have not been a priority for long [70], both of these key players of forest management are expecting contextualisation and flexibility in the modality despite their acceptance of SciFM as a positive move.

Responses of all stakeholders to the higher complexity of implementing SciFM necessitates that the attention of policymakers be focused towards capacity development of forest officials on the ground, as well as of the FUGs. Intensive technical management of natural forests to this extent, at least for Nepal, is new for technicians, as their capacity to facilitate scientific management plans is limited [16,58]. Moreover, human resources outsourced for services such as forest inventory and management plan preparation are also limited, in terms of both numbers and skills [19]. Likewise, local people do not have experience in this form of extensive tree harvesting and management responsibilities and expect intensive support from technicians. However, those outsourced people always concentrate on the completion of their tasks rather than facilitating user group leaders in the process [58]. In addition, poor governance in the timber production chain [25,71-73] has further intensified the complexity. This has increased the dependency of users on outsourced consultants and discouraged deliberations among local people. Such limited deliberations have increased confusion among users, affecting 
forest and group governance. Procedural hassles and corruption, beginning from management plan preparation to tender management and forest product distribution have added to the challenges faced by forest officials and user groups [72]. Limited authority at district level in the timber tender process [19] and the required number of intermittent monitoring and supervision visits from higher authorities have widened the loopholes for corruption, hindering the process and degrading trust in forest officials and stakeholders [70]. As highlighted by Shindler, Brunson and Stankey [61], greater complexity in implementation reduces the adoption rate of any interventions that may jeopardise the SciFM objectives.

Although all the benefits/income from community forests accrue to the respective communities which can invest locally for the benefits of their users, local forest users have perceived higher start-up costs as one of the issues to hinder implementation of SciFM. Since the cost of any innovation has negative relationships with its adoption [53], the response of local FUGs and their networks to excessively high costs presents a key issue for all the stakeholders that may lead to the failure of SciFM. The majority of the respondents from the government and private sector indicated medium costs compared with the benefits, but field studies have found that forest users are worried about higher expenses during start-up. Considering the sensitivity of financial burdens to the FUGs, policy makers and researchers need to explore ways of minimising the costs incurred in both technical assessments and the harvesting processes. For instance, intensive forest inventory and tagging of each tree with Global Positioning System (GPS) techniques might not be necessary [16]. Similarly, adoption of more transparent processes in the selection of service providers may help to convince the forest users.

\subsection{Possible Strategies: Optimising Opportunities and Minimising Risks of SciFM}

The realisation by stakeholders of the need for urgent action to capitalise on its potential contribution to the national and local economy itself provides a vital opportunity to design and implement the best possible forest management option for Nepal's forest production. At the same time, recognition of diversity in forest management modality and ownership in such forests is equally important. For instance, SciFM has been implemented in three major forms of management modalities: national forests, solely managed by the government; collaborative forests, managed jointly by the government and the local users; and community forests, solely managed by the local communities with complete autonomy and self-governance [17]. Despite the similarities in dominant forest types, at least in the production forests of the Tarai region, the key actors who manage forest resources and provisions while sharing costs and benefits are different [74]. Furthermore, differences exist in management capacity, resource potential and understanding of and interest in SciFM even within the CBFM modalities. Hence, separate strategies are crucial to exploit opportunities.

One of the options to increase acceptance and adoption of any intervention is trialability, that is, piloting and demonstrating up to a stage where stakeholders can compare and realize benefits $[52,75]$. Hence, piloting the SciFM in government block forests and demonstrating it to all the stakeholders might enhance adoption of this modality in other management regimes. Likewise, the capacity and experience of the key actors and coordination/collaboration among them will determine the adoption of forest management and harvesting knowledge in production forests [76]. This has further importance for deciding the appropriateness of silviculture/forest management options in community-based forestry [57]. Recognition of the forest management objectives set by the FUGs and facilitating (not imposing) them to simplify the complex inventory system according to their needs will help to optimise opportunities.

Capacity development of the stakeholders, creating a feeling of ownership over SciFM through analysis of social, economic and environmental factors and design of participatory and transparent forest assessment tools may support the enhancement of effectiveness and the adoption of SciFM. Leadership and autonomy in management plan development and selection of service providers will encourage the community to take ownership of the process and will convey positive messages to their networks. Likewise, assessment of resource potential, management capacity and institutional 
governance of CFUGs, as well as their interest in adopting SciFM is critical. More importantly, frequent deliberations with community forest $(\mathrm{CF})$ networks in policy decisions and implementation processes will help assuage their suspicions towards SciFM as a tool for recentralising community forests.

Understanding and promoting the perception of the private sector of SciFM as a way to increase the supply of wood products reflects its motives for increasing the harvesting intensity of natural forests $[70,77]$. Since the private sector is primarily concerned with easy availability of timber rather than other forestry functions [78], its intention to continue SciFM could be predominantly based on its own interests. In the context of increasing timber imports due to the limited harvesting of trees in the country, this interpretation might be also valid. However, SciFM aims beyond timber supply and therefore, this understanding would be incomplete. As far as the local forest users are concerned, their understanding is dominated by the resulting benefits, including income and employment. Nevertheless, their feelings towards the management challenges associated with technical and political aspects of SciFM including technical dominance should be noted. This may discourage them from engaging in forest management in the long run [57], considering the increased financial risks as well as increased responsibilities.

\section{Conclusions}

Forest management policies and practices determine the economic and environmental outcomes in production forests $[76,77]$. However, the effectiveness of such policies and practices relies on the understanding and joint efforts of the key stakeholders. This is important in community-based forestry, in which meaningful engagement of all the key actors determines the success. Acknowledging the roles of stakeholders in forest management, this study has examined the perspectives of key stakeholders in ongoing SciFM initiatives in Nepal. Based on the study findings and discussions above, we conclude that:

1. Despite the converging perspectives of stakeholders on the need for active forest management, stakeholders exhibit differences in understanding/conceptualisation and interpretation of SciFM. The primary reasons for such divergence were highlighted as the implementation modality and nomenclature of SciFM in the outer layer, whereas the political economy of the stakeholder institutions and historically engrained scepticisms towards each other potentially played key roles beneath the surface.

2. Such divergences will lead to negative implications for the future of forests and communities if the stakeholders cannot instigate steps towards regular and fruitful deliberations on the most suitable modality of forest management. Despite the fact that the Ministry of Forest and Environment, as a lead policy driver, and FECOFUN, as a responsible umbrella institution as well as a representative of more than 22,000 CFUGs, need to initiate discussions proactively, the role of other stakeholders is equally important to reach a satisfactory solution.

3. Considering the positive results on compatibility and the relative advantages of SciFM, this kind of active forest management intervention could be the right choice to increase timber supply, contribute to local and national economy and improve forest health [77]. However, at the same time, lengthy bureaucratic procedures, complex rules and regulations and dominance of forestry technicians have increased distrust among the stakeholders. This has created dilemmas at the implementation level and increased the reluctance of forest users and networks to collaborate in SciFM. Bureaucratic dominance in the process has made the stakeholders (particularly FECOFUN) suspicious about the possibility of recentralisation of community rights and ownership in forest management. Therefore, ensuring genuine participatory forest governance could help SciFM to gain expected momentum.

4. Conventional thinking of key forestry actors and scepticism towards each other based on their past forest management behaviours and actions needs to change within the broader goals of benefitting communities, the nation and the environment. To be specific, the common government perception of forestry networks as problem makers and the network's observation of government 
as the promoter of technocratic solutions need to be reconsidered in order to build trust. Capacity development of the stakeholders, including forest officials, and the design of participatory and transparent forest assessment tools may support the reduction of scepticism, thereby enhancing effectiveness in SciFM adoption.

5. As SciFM has already been in place for the last 7 years, broader implications of SciFM for forest product supply, the local and the national economy and the area of potential changes to modality based on learning and existing knowledge could be further areas of research to manage production forests of Nepal in a sustainable way. Likewise, periodic assessment of management capacity and institutional governance of forest user groups is essential.

Author Contributions: B.H.P., conceptualisation and writing; T.M., overall guidance and concept framing; G.C., overall guidance and concept framing. All authors have read and agreed to the published version of the manuscript.

Funding: The work was supported by Office of the Research Graduate Studies (ORGS) of University of Southern Queensland and Students Research Grant under Hariyo Ban Program funded by USAID and implemented by WWF Nepal.

Acknowledgments: The authors wish to acknowledge the cooperation and support from the Department of Forests and Soil Conservation, Nepal to design and carry out this study. Community members, experts and all forestry stakeholders are acknowledged for their time and information. We highly appreciate the data collection support from Roshan Bhandari and Yubaraj Acharya. We are grateful to Barbara Harmes, Susette Eberhard and Susanne Holzknecht for their editorial support. Finally, four anonymous reviewers are highly acknowledged for their time and efforts to offer us the constructive comments that helped us a lot to improve our paper.

Conflicts of Interest: Authors have declared no any conflict of interest.

\section{References}

1. Gual, M.A.; Norgaard, R.B. Bridging ecological and social systems coevolution: A review and proposal. Ecol. Econ. 2010, 69, 707-717. [CrossRef]

2. Kallis, G.; Norgaard, R.B. Coevolutionary ecological economics. Ecol. Econ. 2010, 69, 690-699. [CrossRef]

3. Ostrom, E. A general framework for analyzing sustainability of social-ecological systems. Science 2009, 325, 419-422. [CrossRef] [PubMed]

4. Krott, M.; Bader, A.; Schusser, C.; Devkota, R.; Maryudi, A.; Giessen, L.; Aurenhammer, H. Actor-centred power: The driving force in decentralised community based forest governance. For. Policy Econ. 2014, 49, 34-42. [CrossRef]

5. Schmithüsen, F. Three hundred years of applied sustainability in forestry. Unasylva 2013, 64, 3-11.

6. Wiersum, K.F. 200 years of sustainability in forestry: Lessons from history. Environ. Manag. 1995, 19, 321-329. [CrossRef]

7. Siiskonen, H. The conflict between traditional and scientific forest management in 20th century Finland. For. Ecol. Manag. 2007, 249, 125-133. [CrossRef]

8. Food and Agriculture Organisation of the United Nations. Global Forest Resources Assessment 2015: How Are the World's Forests Changing? Food and Agriculture Organisation of the United Nations (FAO): Rome, Italy, 2016.

9. Sarre, A.; Sabogal, C. Is SFM an impossible dream? Unasylva 2013, 64, 240.

10. Wijewardana, D. Sustainable Forest Management: What Does It Mean in Practice? UN Forum on Forests Secretariat: New York, NY, USA, 2007; pp. 5-7.

11. Gustafsson, L.; Baker, S.C.; Bauhus, J.; Beese, W.J.; Brodie, A.; Kouki, J.; Lindenmayer, D.B.; Lõhmus, A.; Pastur, G.M.; Messier, C. Retention forestry to maintain multifunctional forests: A world perspective. BioScience 2012, 62, 633-645. [CrossRef]

12. Mendoza, G.A.; Prabhu, R. Combining participatory modeling and multi-criteria analysis for community-based forest management. For. Ecol. Manag. 2005, 207, 145-156. [CrossRef]

13. Kearney, A.R.; Bradley, G.; Kaplan, R.; Kaplan, S. Stakeholder perspectives on appropriate forest management in the pacific northwest. For. Sci. 1999, 45, 62-73. [CrossRef]

14. Julijanti, J.; Nugroho, B.; Kartodihardjo, H.; Nurrochmat, D.R. Policy adoption of forest management unit: A knowledge diffusion analysis. J. Manaj. Hutan Trop. 2014, 20, 94-102. [CrossRef] 
15. Bhattarai, B.P.; Poudyal, B.H.; Acharya, R.P.; Maraseni, T. Policy and governance issues in timber harvesting: A case study of collaborative forest in Nepal. In Wild Harvests, Governance, and Livelihoods in Asia, Proceedings of the International Conference, Kathmandu, Nepal, 30 November-2 December 2017; Ministry of Population and Environment (MOPE): Kathmandu, Nepal, 2017; p. 186.

16. Poudel, K.C. Silviculture for forest management in Nepal. Banko Janakari 2018, 27, 15-20. [CrossRef]

17. Baral, S.R.; Dhakal, S.R. Nepalma Baigyanik Ban Byabasthapan: Bartaman Abastha, Samasya ra Sujhab; Babarmahal: Kathmandu, Nepal, 2018.

18. Ministry of Forests and Soil Conservation. Scientifc Forest Management Guideline; Ministry of Forests and Soil Conservation, Singhadarbar: Kathmandu, Nepal, 2014.

19. Koirala, P.N.; Acharya, K. Sivicultural evolution: A retrospective review to uncover appropriate lessons for forestry advance in Nepal. In Proceedings of the Silviculture for Forest Management Kathmandu, Kathmandu, Nepal, 19-21 February 2017; p. 540.

20. Subedi, B.P.; Ghimire, P.L.; Koontz, A.; Khanal, S.C.; Katwal, P.; Sthapit, K.R.; Mishra, S.K. Private Sector Involvement and Investment in Nepal's Forestry: Status, Prospects and Ways Forward; Multi Stakeholder Forestry Programme (MSFP): Kathmandu, Nepal, 2014.

21. Department of Forest Research and Survey. State of Nepal's Forests; Forest Resource Assessment (FRA) Nepal, Department of Forest Research and Survey (DFRS): Kathmandu, Nepal, 2015.

22. Jayasawal, D.; Bishwokarma, D. Scientific Forest Management Initiatives in Nepal: MSFP Experiences and Lessons Learnt; Multi Stakeholder Forestry Programme: Kathmandu, Nepal, 2016.

23. Department of Customs. Foreign Trade Statistics FY 2075/76 (2018/19), Government of Nepal, Kathmandu. Available online: https://www.customs.gov.np/en/monthlystatstics.html (accessed on 18 September 2019).

24. Subedi, V.R.; Poudel, I.; Bhattarai, P. Application of silviculture system, yield regulation and thinning in natural forests. In Proceedings of the Silviculture for Forest Management Nepal, Kathmandu, Nepal, 19-21 February 2017; p. 540.

25. Banjade, M.R.; Paudel, N.S.; Karki, R.; Sunam, R.; Paudyal, B.R. Putting Timber in the Hot Seat: Discourse, Policy and Contestations over Timber in Nepal; ForestAction Discussion Paper Series 11: 2; ForestAction: Kathmandu, Nepal, 2011.

26. Paudel, N.; Paudel, G.; Karki, R.; Khatri, D. Revenue and Employment Opportunities from Timber Management in Nepal's Community Forests; Policy Brief; ForestAction: Kathmandu, Nepal, 2014.

27. Basnyat, B.; Treue, T.; Pokharel, R. Silvicultural madness: A case from the "Scientific Forestry" initiative in the community forests of Nepal. Banko Janakari 2018, 27, 54-64. [CrossRef]

28. Baral, S.; Meilby, H.; Khanal Chettri, B.B.; Basnyat, B.; Rayamajhi, S.; Awale, S. Politics of getting the numbers right: Community forest inventory of Nepal. For. Policy Econ. 2018, 91, 19-26. [CrossRef]

29. Basnyat, B.; Treue, T.; Pokharel, R.K.; Lamsal, L.N.; Rayamajhi, S. Legal-sounding bureaucratic re-centralisation of community forestry in Nepal. For. Policy Econ. 2018, 91, 5-18. [CrossRef]

30. Rutt, R.L.; Chhetri, B.B.K.; Pokharel, R.; Rayamajhi, S.; Tiwari, K.; Treue, T. The scientific framing of forestry decentralization in Nepal. For. Policy Econ. 2015, 60, 50-61. [CrossRef]

31. Joshi, O.; Parajuli, R.; Kharel, G.; Poudyal, N.C.; Taylor, E. Stakeholder opinions on scientific forest management policy implementation in Nepal. PLoS ONE 2018, 13, e0203106. [CrossRef]

32. Subedi, V.; Bhatta, K.; Poudel, I.; Bhattarai, P. Application of silvicultural system, yield regulation and thinning practices in natural forests: Case study from western Terai. Banko Janakari 2018, 92-97. [CrossRef]

33. Cedamon, E.; Paudel, G.; Basyal, M.; Nuberg, I.; Shrestha, K. Applications of single-tree selection guideline following a DBq approach on Nepal's community forests. Banko Janakari 2018, 104-112. [CrossRef]

34. Gilmour, D. Forty Years of Community-Based Forestry: A Review of Its Extent and Effectiveness; Food and Agriculture Organisation of the United Nations: Rome, Italy, 2016.

35. Maraseni, T.N.; Bhattarai, N.; Karky, B.S.; Cadman, T.; Timalsina, N.; Bhandari, T.S.; Apan, A.; Ma, H.O.; Rawat, R.; Verma, N. An assessment of governance quality for community-based forest management systems in Asia: Prioritisation of governance indicators at various scales. Land Use Policy 2019, 81, 750-761. [CrossRef]

36. Williams, B.K. Adaptive management of natural resources-Framework and issues. J. Environ. Manag. 2011, 92, 1346-1353. [CrossRef] [PubMed]

37. Pokharel, B.K.; Branney, P.; Nurse, M.; Malla, Y.B. Community forestry: Conserving forests, sustaining livelihoods and strengthening democracy. J. For. Livelihood 2007, 6, 8-19. 
38. Maraseni, T.N.; Dargusch, P. Expanding woodland regeneration on marginal southern Queensland pastures using market-based instruments: A landowners' perspective. Australas. J. Environ. Manag. 2008, 15, 104-112. [CrossRef]

39. Krott, M. Forest Policy Analysis; Springer Science \& Business Media: New York, NY, USA, 2005.

40. Rahman, M.S.; Giessen, L. Mapping international forest-related issues and main actors' positions in Bangladesh. Int. For. Rev. 2014, 16, 586-601. [CrossRef]

41. Raum, S. A framework for integrating systematic stakeholder analysis in ecosystem services research: Stakeholder mapping for forest ecosystem services in the UK. Ecosyst. Serv. 2018, 29, 170-184. [CrossRef]

42. Sandström, C.; Carlsson-Kanyama, A.; Lindahl, K.B.; Sonnek, K.M.; Mossing, A.; Nordin, A.; Nordström, E.-M.; Räty, R. Understanding consistencies and gaps between desired forest futures: An analysis of visions from stakeholder groups in Sweden. Ambio 2016, 45, 100-108. [CrossRef]

43. Sténs, A.; Bjärstig, T.; Nordström, E.-M.; Sandström, C.; Fries, C.; Johansson, J. In the eye of the stakeholder: The challenges of governing social forest values. Ambio 2016, 45, 87-99. [CrossRef]

44. Lintangah, W.; Weber, N. Implementation of sustainable forest management: An application of the triple perspective typology of stakeholder theory in a case study in Sabah, Malaysia. J. For. Landsc. Res. 2015, 1, 1-11.

45. Steurer, R. Mapping stakeholder theory anew: From the 'stakeholder theory of the firm' to three perspectives on business-society relations. Bus. Strategy Environ. 2006, 15, 55-69. [CrossRef]

46. Dyllick, T.; Hockerts, K. Beyond the business case for corporate sustainability. Bus. Strategy Environ. 2002, 11, 130-141. [CrossRef]

47. Reed, M.S.; Graves, A.; Dandy, N.; Posthumus, H.; Hubacek, K.; Morris, J.; Prell, C.; Quinn, C.H.; Stringer, L.C. Who's in and why? A typology of stakeholder analysis methods for natural resource management. J. Environ. Manag. 2009, 90, 1933-1949. [CrossRef] [PubMed]

48. Yin, R.K. Qualitative Research from Start to Finish; Guilford Publications: New York, NY, USA, 2015.

49. Babbie, E.R. The Practice of Social Research; Nelson Education: Toronto, ON, Canada, 2015.

50. Timberlake, T.J.; Schultz, C.A. Policy, practice, and partnerships for climate change adaptation on US national forests. Clim. Chang. 2017. [CrossRef]

51. Neuman, L.W. Social Research Methods: Qualitative and Quantitative Approaches; SAGE: Southend Oaks, CA, USA, 2002.

52. Rogers, E.M.; Shoemaker, F.F. Communication of Innovations; A Cross-Cultural Approach; The Free Press: New York, NY, USA, 1971.

53. Tornatzky, L.G.; Klein, K.J. Innovation characteristics and innovation adoption-implementation: A meta-analysis of findings. IEEE Trans. Eng. Manag. 1982, EM-29, 28-45. [CrossRef]

54. Poudyal, B.H.; Paudel, G.; Luintel, H. Enhancing REDD+ outcomes through improved governance of community forest user groups. J. For. Livelihood 2013, 11, 14-26. [CrossRef]

55. Maraseni, T.N.; Cockfield, G.; Apan, A. Community based forest management systems in developing countries and eligibility for clean development mechanism. J. For. Livelihood 2005, 4, 31-42.

56. Cadman, T.; Maraseni, T.; Breakey, H.; Loópez-Casero, F.; Ma, H. Governance values in the climate change regime: Stakeholder perceptions of REDD+ legitimacy at the national level. Forests 2016, 7, 212. [CrossRef]

57. Gilmour, D. Silviculture and community forestry: Looking backwards, looking forwards. In Proceedings of the 1st National Silviculture Workshop, Kathmandu, Nepal, 20 August 2017; pp. 27-50.

58. Sapkota, L.; Dhungana, H.; Poudyal, B.; Chapagain, B.; Gritten, D. Understanding the barriers to community forestry delivering on its potential: An illustration from two heterogeneous districts in Nepal. Environ. Manag. 2019, in press.

59. Rydin, Y.; Pennington, M. Public Participation and Local Environmental Planning: The collective action problem and the potential of social capital. Local Environ. 2000, 5, 153-169. [CrossRef]

60. Head, B.W.; Alford, J. Wicked problems: Implications for public policy and management. Adm. Soc. 2015, 47, 711-739. [CrossRef]

61. Shindler, B.A.; Brunson, M.; Stankey, G.H. Social Acceptability of Forest Conditions and Management Practices: A Problem Analysis; General Technical Report; United States Department of Agriculture: Washington, DC, USA, 2002. 
62. Ojha, H.R.; Banjade, M.R.; Sunam, R.K.; Bhattarai, B.; Jana, S.; Goutam, K.R.; Dhungana, S. Can authority change through deliberative politics? Lessons from the four decades of participatory forest policy reform in Nepal. For. Policy Econ. 2014, 46, 1-9. [CrossRef]

63. Sunam, R.; Paudel, G. Democratising Nepal's forest sector policy process: The role of resistance by community federation. J. For. Livelihood 2012, 10, 28-41. [CrossRef]

64. Sunam, R.K.; Paudel, N.S.; Paudel, G. Community forestry and the threat of recentralization in Nepal: Contesting the bureaucratic hegemony in policy process. Soc. Nat. Resour. 2013, 26, 1407-1421. [CrossRef]

65. Satyal Pravat, P.; Humphreys, D. Using a multilevel approach to analyse the case of forest conflicts in the Terai, Nepal. For. Policy Econ. 2013, 33, 47-55. [CrossRef]

66. Dhungana, S.P.; Satyal, P.; Yadav, N.P.; Bhattarai, B. Collaborative forest management in Nepal: Tenure, governance and contestations. J. For. Livelihood 2017, 15, 27-42. [CrossRef]

67. Bampton, J.F.; Ebregt, A.; Banjade, M.R. Collaborative forest management in Nepal's Terai: Policy, practice and contestation. J. For. Livelihood 2007, 6, 30-43.

68. Ribot, J.C.; Agrawal, A.; Larson, A.M. Recentralizing while decentralizing: How national governments reappropriate forest resources. World Dev. 2006, 34, 1864-1886. [CrossRef]

69. Poudyal, B.H.; Maraseni, T.; Cockfield, G. Impacts of forest management on tree species richness and composition: Assessment of forest management regimes in Tarai landscape Nepal. Appl. Geogr. 2019, 111, 102078. [CrossRef]

70. Poudyal, B.; Maraseni, T.; Cockfield, G. An assessment of the policies and practices of selective logging and timber utilisation: A case study from natural forests of Tarai Nepal and Queensland Australia. Land Use Policy 2019, 91, 104422. [CrossRef]

71. Gritten, D.; Greijmans, M.; Lewis, S.R.; Sokchea, T.; Atkinson, J.; Quang, T.N.; Poudyal, B.; Chapagain, B.; Sapkota, L.M.; Mohns, B. An uneven playing field: Regulatory barriers to communities making a living from the timber from their forests-examples from Cambodia, Nepal and Vietnam. Forests 2015, 6, 3433-3451. [CrossRef]

72. Goutam, K.R. Corruption in Timber Production and Trade: An Analysis Based on Case Studies in the Tarai of Nepal. Ph.D. Thesis, Australian National University, Canberra, Australia, 2017.

73. Cadman, T.; Maraseni, T.; Ma, H.O.; Lopez-Casero, F. Five years of REDD plus governance: The use of market mechanisms as a response to anthropogenic climate change. For. Policy Econ. 2017, 79, 8-16. [CrossRef]

74. Maraseni, T.N.; Shivakoti, G.P.; Cockfield, G.; Apan, A. Nepalese non-timber forest products: An analysis of the equitability of profit distribution across a supply chain to India. Small Scale For. Econ. Manag. Policy 2006, 5, 191-206. [CrossRef]

75. Pannell, D.J.; Marshall, G.R.; Barr, N.; Curtis, A.; Vanclay, F.; Wilkinson, R. Understanding and promoting adoption of conservation practices by rural landholders. Aust. J. Exp. Agric. 2006, 46, 1407-1424. [CrossRef]

76. Poudyal, B.H.; Maraseni, T.; Cockfield, G. Evolutionary dynamics of selective logging in the tropics: A systematic review of impact studies and their effectiveness in sustainable forest management. For. Ecol. Manag. 2018, 430, 166-175. [CrossRef]

77. Poudyal, B.H.; Maraseni, T.N.; Cockfield, G. Implications of selective harvesting of natural forests for forest product recovery and forest carbon emissions: Cases from Tarai Nepal and Queensland Australia. Forests 2019, 10, 693. [CrossRef]

78. Sakurai, T.; Rayamajhi, S.; Pokharel, R.K.; Otsuka, K. Efficiency of timber production in community and private forestry in Nepal. Environ. Dev. Econ. 2004, 9, 539-561. [CrossRef]

(C) 2019 by the authors. Licensee MDPI, Basel, Switzerland. This article is an open access article distributed under the terms and conditions of the Creative Commons Attribution (CC BY) license (http://creativecommons.org/licenses/by/4.0/). 